\title{
KAJIAN TOTAL BAKTERI DAN KADAR HISTAMIN TUNA PASCA TANGKAP DI PERAIRAN SANGIHE
}

\author{
Study of Total Bacteria and Histamine Levels of Post-Capture Tuna \\ in Sangihe Waters
}

Stevy Imelda Murti Wodi, Eko Cahyono

Dosen Program Studi Teknologi Pengolahan Hasil Laut, Politeknik Negeri Nusa Utara

Jl. Kesehatan No.1 Tahuna

Email: wodiimelda@gmail.com

\begin{abstract}
Abstrak: Tuna yang berkualitas sangat ditentukan oleh penanganan pasca tangkap, yang kita akui aspek-aspek pasca tangkap ini belum merata dikuasai oleh masyarakat nelayan di Kepulauan Sangihe, sehingga mengakibatkan permasalahan keamanan pangan terutama kadar histamin yang melampaui batas. Histamin terbentuk akibat adanya kesalahan selama proses penanganan dan pengolahan. Tingginya temperatur adalah penyebab utama terbentuknya histamin. Histamin dapat menyebabkan keracunan pada orang yang mengkonsumsinya. Penelitian ini bertujuan untuk menentukan total bakteri dan kadar histamin tuna pasca tangkap di perairan Sangihe. Parameter uji dalam penelitian ini meliputi pengambilan dan preparasi sampel, Uji total bakteri, dan kadar histamin pada tuna segar. Analisis histamin menggunakan metode Enzyme Linked Immunosorbent Assay (ELISA). Hasil penelitian menunjukan bahwa TPC pada ketiga lokasi, yaitu Kauhis 9,7 x $10^{4}$ cfu/g Santiago $2,8 \times 10^{4} \mathrm{cfu} / \mathrm{g}$ masih memenuhi standar SNI untuk tuna segar yaitu $5,0 \times 10^{5} \mathrm{cfu} / \mathrm{g}$, sedangkan pada pasar Towo 8,2 x $10^{5} \mathrm{cfu} / \mathrm{g}$ telah melewati batas standar. Kadar histamin dari ketiga lokasi masih dikategorikan sangat aman $<5$ ppm dari standar yaitu 100 ppm.
\end{abstract}

Kata kunci : Bakteri, Histamin, Ikan, Mutu, Tuna

\begin{abstract}
Quality tuna is very much determined by post-capture handling, which we admit that these post-catch aspects have not been evenly controlled by the fishing community in the Sangihe Islands, resulting in food safety problems, especially histamine levels that exceed the limit. Histamine is formed due to errors during the handling and processing process. The high temperature is the main cause of the formation of histamine. Histamine can cause poisoning in people who take it. This study aims to determine the total bacteria and histamine levels of post-caught tuna in Sangihe waters. The test parameters in this study include sample collection and preparation, total bacterial test, and histamine levels in fresh tuna. Histamine analysis used the Enzyme-Linked Immunosorbent Assay (ELISA) method. The results showed that the TPC in the three locations, namely Kauhis 9.7 x 104 CFU / g Santiago 2.8 x 104 CFU / g still met the SNI standard for fresh tuna, namely 5.0 x $105 \mathrm{CFU} / \mathrm{g}$, while in the Towo 8 market, 2 x $105 \mathrm{CFU} / \mathrm{g}$ has exceeded the standard limit. The histamine levels from the three locations were still categorized as very safe $<5$ ppm from the standard, namely $100 \mathrm{ppm}$.
\end{abstract}

Keyword: Bacteria, Histamine, Fish, Quality, Tuna

\section{PENDAHULUAN}

Kabupaten Kepulauan Sangihe sebagai wilayah perairan Nusa Utara merupakan jalur imigrasi ikan pelagis terutama jenis tuna dan juga sebagai salah satu daerah penghasil tuna yang menembus pasar Internasional. Berdasarkan data Kementerian Kelautan dan Perikanan, potensi perikanan tangkap di Kabupaten
Kepulauan Sangihe adalah sekitar 34.000 ton atau setara dengan 9\% dari potensi total Wilayah Pengelolaan Perikanan Negara Republik Indonesia (WPPNRI) 716, dengan jumlah produksi tuna Madidihang (Thunnus albacares) 656,05 ton. Dari potensi tersebut yang baru termanfaatkan berdasarkan 
data 2014 adalah 8.502 ton atau sekitar 25\% (BPS Sangihe, 2014)

Tuna merupakan komoditi primadona tidak hanya dipasar lokal tapi juga ekspor untuk permintaan wilayah Asia, Amerika, Australia dan Eropa, karena memiliki kandungan protein yang tinggi. Selain itu, tuna juga memiliki kandungan histamin yang dapat dijadikan salah satu indikator kesegaran ikan tuna. Kebutuhan permintaan ekspor tuna tiap tahun meningkat meskipun kebijakan moratorium menteri perikanan sempat membuat ekspor menurun dari Indonesia akibat "illegal fishing". Hal ini membuat harga tuna di pasar ekspor cukup menjanjikan dan menjadi peluang besar bagi masyarakat nelayan. Tentunya harga ekspor juga berkaitan dengan jaminan mutu kesegaran yang terbaik. Standar mutu tuna ekspor mutlak adalah berkualitas prima atau Best Grade (Grade A). Untuk mendapatkan mutu tuna yang berkualitas sangat ditentukan oleh penanganan pasca tangkap, yang kita akui aspek-aspek pasca tangkap ini belum merata dikuasai oleh masyarakat nelayan di Kepulauan Sangihe, sehingga mengakibatkan permasalahan keamanan pangan terutama kadar histamin yang melampaui batas. Hal ini disebabkan karena minimnya ketersediaan suplai es balok, kurangnya pengetahuan nelayan akan konsep pemasaran tuna terkait dengan standar baku mutu yang objektif membuat nelayan kadang dibodohi, serta akses pasar yang terbatas (Setiawan et al, 2016)

Histamin terbentuk akibat adanya kesalahan selama proses penanganan dan pengolahan. Tingginya temperatur $\left(>20^{\circ} \mathrm{C}\right)$ adalah penyebab utama terbentuknya histamin (Taylor et al 2002 dalam Wodi et al 2018). Histamin dapat menyebabkan keracunan pada orang yang mengkonsumsinya. Histamin pada tuna dihasilkan dari kontaminasi asam amino histidin yang terkandung dalam ikan oleh bakteri dan mengeluarkan enzim histidin dekarboksilase yang selanjutnya menjadi histamin. Menurut Milo et al,
(2013), suhu dan waktu penyimpanan dapat mempengaruhi peningkatan kadar histamin pada ikan tuna. Terdapat interaksi antara waktu dan suhu penyimpanan terhadap kadar histamin serta kandungan bakteri pada tuna. Hasil penelitian Di wang et al (2020) menyatakan bahwa bakteri pembentuk histamin dapat tumbuh dengan baik pada suhu $20^{\circ} \mathrm{C}$ dengan $\mathrm{pH} 7$. Hasil penelitian lain menunjukkan bahwa pembentukan histamin dapat terhambat pada suhu rendah $0^{\circ} \mathrm{C}$ atau lebih rendah lagi. Industri tuna menerapkan penanganan tuna dengan suhu rendah untuk mencegah terbentuknya histamin. Namun demikian, kendala yang dihadapi masyarakat nelayan di Kepulauan Sangihe adalah belum adanya pabrik Es Balok/Cold Storage serta perusahaan pengolahan ikan yang bisa menampung hasil tangkapan nelayan, sehingga ikan tuna hasil tangkapan nelayan dikirim ke Manado dan Bitung dan sebagian dijual lokal di pasar tradisional dan dikonsumsi sendiri. Oleh karena itu diperlukan penelitian untuk mengetahui mutu mikriobiologis dan kandungan histamin pada tuna pasca tangkap di perairan Kepulauan Sangihe.

\section{METODE PENELITIAN}

\section{Bahan dan Alat}

Bahan baku yang digunakan adalah ikan Tuna segar yang diperoleh dari kampung Kauhis, Santiago dan pasar Towo Tahuna. Bahan lain yang digunakan adalah alkohol, media PCA, Nacl, aquades dan bahan lain untuk analisa mikrobiologi. Sedangkan alat yang digunakan dalam penelitian ini adalah erlenmeyer, gelas ukur, pisau, timbangan digital, blender, laminary flow, cawan petri, termometer, bunsen, spatula, pipet, ose, inkubator, autoklaf, talenan, colony counter, sentrifuse, spektrofluotometri, Histamine Enzymatic Assay Test Kit. 


\section{Jenis dan Sumber Data}

Data yang diperlukan dalam penelitian ini bersumber dari data primer maupun data sekunder. Data primer diperoleh secara langsung dari hasil uji yang dilakukan. Sedangkan data sekunder diperoleh secara tidak langsung melalui studi literatur.

\section{Analisis Data}

Analisis data dilakukan dengan menelaah data yang diperoleh melalui data primer maupun data sekunder yang dilakukan secara deskriptif.

\section{HASIL DAN PEMBAHASAN}

Sampel ikan tuna yang digunakan dalam penelitian ini didaratkan baik di kampung Kauhis, Santiago maupun di Pasar Tradisional Towo Tahuna, adalah Jenis sirip kuning ( $T$. albacares) yang merupakan hasil tangkapan di perairan kepulauan Sangihe. Ikan tuna yang ditangkap menggunakan long line, kemudian dimatikan segera untuk mencegah terjadinya penurunan mutu. Kapal penangkap yang digunakan nelayan masih tergolong sederhana dan belum dilengkapi dengan sistem pendingin. Pada umumnya nelayan hanya membawa coolbox/styrofoam berisi 30 - 70 butir es rumahan. Waktu penangkapan relatif singkat yaitu one day fishing, artinya mereka pergi pada sore hari untuk melaut dan kembali pada keesokan harinya pada waktu pagi hari.

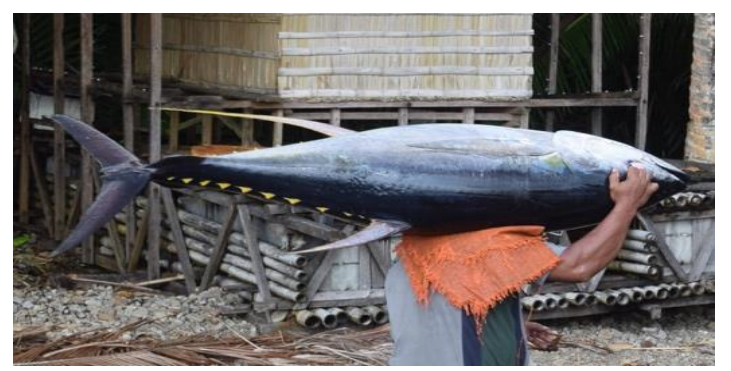

Gambar 1. Hasil tangkapan tuna

\section{Nilai Total Plate Count (TPC)}

Rantai penanganan yang panjang dan lama mulai dari penangkapan, penyimpanan, pengolahan hingga distribusi pada Tuna dapat meningkatkan potensi kontaminasi mikroorganisme. Mikroba merupakan salah satu penyebab utama gangguan kesehatan pada bahan pangan, khususnya pangan ikani yang sifatnya Perishable food. Adanya pertumbuhan akibat kontaminasi mikroba pada bahan pangan dapat menyebabkan kerusakan dan kemunduran kualitas yang ditandai dengan adanya perubahan-perubahan penampakan, bau, rasa, tekstur dan terbentuknya komponen-komponen yang bersifat racun, sehingga menjadi tidak layak untuk dikonsumsi dan berbahaya bagi kesehatan (Hidayat et al. 2006 dalam Wodi et al. 2014).

Analisis total mikroba atau TPC dilakukan untuk mengetahui angka pertumbuhan mikroorganisme setelah contoh diinkubasi dalam media agar pada suhu $35^{\circ} \mathrm{C}$ selama 48 jam sehingga membentuk koloni yang dapat langsung dihitung yang merupakan indikator mikrobiologi kesegaran ikan tuna. Hasil analisis TPC ikan tuna dapat dilihat pada Tabel 1.

Tabel 1. Rata-rata nilai TPC ikan tuna dalam koloni/gr

\begin{tabular}{clc}
\hline No & Lokasi & $\begin{array}{c}\text { Nilai TPC } \\
(\text { Kol/gr })\end{array}$ \\
\hline 1 & Kauhis & $9,7 \times 10^{4}$ \\
2 & Santiago & $2,8 \times 10^{4}$ \\
3 & Pasar Towo & $8,2 \times 10^{5}$ \\
\hline
\end{tabular}

Standar nilai total bakteri (TPC) yang sudah ditetapkan untuk ikan tuna segar yaitu $5 \times 10^{5} \mathrm{CFU} / \mathrm{g}$ (BSN 2006b). Penentuan TPC menggunakan2 kali pengulangan dengan 1 kontrol. Hasil penelitian menunjukan bahwa terjadi perbedaan jumlah bakteri 
pada ketiga lokasi pendaratan tuna. Kandungan TPC pada lokasi pasar Towo tergolong tinggi yaitu $8,2 \times 10^{5}$ $\mathrm{kol} / \mathrm{gr}$ dan melebihi standar Total bakteri yang disyaratkan oleh SNI yaitu $5,0 \times 10^{5} \mathrm{kol} / \mathrm{gr}$. Hal ini disebabkan oleh karena waktu penanganan yang lama sehingga meningkatkan potensi kontaminasi dan peningkatan pertumbuhan jumlah mikroba.

\section{Kadar Histamin Ikan Tuna}

Ikan tuna segar tidak mengandung histamin tetapi memiliki kandungan histidin dalam jumlah besar pada jaringan dagingnya. Histamin akan terbentuk dari histidin selama proses pembusukan terjadi oleh bakteri yang memiliki enzim histidin dekarboksilase (Taylor \& Speckhard 1983). Hasil analisi kadar histamin dari ketiga lokasi dapat dilihat pada Tabel 2.

Tabel 2. Kadar histamin ikan tuna

\begin{tabular}{llc}
\hline No & \multicolumn{1}{c}{ Lokasi } & Kadar histamin (ppm) \\
\hline 1 & Kauhis & 4,32 \\
2 & Santiago & 4,45 \\
3 & Pasar Towo & 4,87
\end{tabular}

Hasil penelitian menunjukan bahwa kadar histamin dari ketiga lokasi masih memenuhi batas standar yang ditetapkan. Batas yang ditentukan oleh Uni Eropa untuk histamin adalah 100 ppm. Seluruh negara memiliki persyaratan teknis histamin lebih ketat dari uni Eropa, kecuali Indonesia dan Codex Alimentarius Commission. Alasan ilmiah yang mendasari penetapan persyaratan teknis histamin Amerika Serikat dan Kanada ialah distribusi histamin yang tidak merata dalam daging ikan sehingga kemungkinan adanya bagian lain dari tuna dengan kadar histamin 500 ppm jika ditemukan kadar histamin 50 ppm pada salah satu bagian daging lainnya. Jepang menetapkan batas histamin 50 ppm karena konsumsi tuna lebih banyak ditujukan untuk konsumsi mentah (sashimi dan sushi) sehingga membutuhkan kualitas tuna yang prima (Wodi et al. 2018). Batas Hanya ikan yang mengandung histidin bebas di atas $100 \mathrm{mg} / 100 \mathrm{~g}$ yang mampu menghasilkan histamin (Mangunwardoyo et al. 2007). Peningkatan jumlah histamine disebabkan oleh beberapa faktor seperti suhu, jenis bahan baku dan banykanya bakteri pengahsil histidine dekarboksilase dalam jaringan daging ikan merupakan faktor yang mempengaruhi dalam pembentukan histamine

\section{KESIMPULAN}

Berdasarkan hasil penelitian dapat disimpulkan bahwa jumlah total bakteri (TPC) pada lokasi Kampung Kauhis dan Santiago belum melewati ambang batas, sedangkan pada Pasar Towo telah melewati ambang batas yang telah ditetapkan. Kadar histamin pada ketiga lokasi masih memenuhi persyaratan $<5$ ppm.

\section{DAFTAR RUJUKAN}

Affiano I. 2011. Analisis perkembangan histamine tuna (Thunnus sp) dan bakteri pembentuk nya pada beberapa setting standar suhu penyimpanan [Skripsi]. Fakultas Perikanan dan Ilmu Kelautan. Institut Pertanian Bogor.

Bremner PJ, Fletcher GC. Osborne C. 2003. Scombrotoxin in seafood. Christshurch:New Zealand Institute for Crop and Food Research Limid.

BPS Sangihe. 2014. Sangihe dalam angka. Badan pusat statistik Kabupaten Kepulauan Sangihe.http://sangihekab.bps.go.id/

[BSN] Badan Standardisasi Nasional. 2006. Cara Uji Mikrobiologi - Bagian 3: Penentuan Angka Lempeng Total (ALT) pada Produk Perikanan. SNI 01- 2332.3-2006. Jakarta (ID): Badan Standardisasi Nasional.

[BSN] Badan Standardisasi Nasional. 2009a. Cara Uji Kimia - Bagian 10. Penentuan Kadar Histamin dengan Spektroflorometri dan Kromatografi Cair Kinerja Tinggi (KCKT) pada Produk Perikanan. SNI 2354.10:2009. Jakarta (ID): Badan Standardisasi Nasional. 
Dalgaard P, Emborg J, Kjolby A, Sorensen ND, Ballin NZ. 2008. Histamine and biogenic amines: formation and importance in seafood. $\mathrm{T}$ Borresen, edited, Improving Seafood Product for Customer. North America:Woodhead PublishCRC Press LLC.

Di Wang, Yamaki S, Kawai Y, Yamazaki K. 2020. Histamine production behaviors of a psychrotolerant histamine-producer, Morganella psychrotolerans, in various environmental conditions. Current Microbiology. 77.460-467

[FDA] Food and Drug Administration. 2010. Detention without physical examination of seafood and seafood products from specific manufacturers/shippers due to decomposition and/or histamines. http://www.fda.gov

[FAO] Food and Agriculture Organization. 1995. Quality and Quality Changes in fresh fish. Huss HH, editor.Rome:FAO.

[FDA] Food and Drug Administration. 2011. Scombrotoxin (histamine) formation. Didalam: Fish and Fishery Product Hazards and Control Guide. Washington (US): Department of Health and Human Service, Center for Food safety and applied nutrition.

Keer M, Paul L, Sylvia A, Carl R. 2002. Effect of storage condition on histamine formation in fresh and canned tuna. Victoria: Comissioned by Food Safety Unit.

Lehane L, Olley J. 2000. Histamine fish poisoning revisited. International Journal of Food Microbiology. 58:1-37.

Mangunwardoyo W, Sophia RA, Heruwati ES. 2007. Seleksi dan pengujian aktivitas enzim Lhistidine decarboxylase dari bakteri pembentuk histamin. Makara Sains. 11:104-109.
Milo SM, LME Purwijatiningsih, Pranata S. 2013. Mutu ikan tongkol di kabupaten Gunung Kidul dan Sleman Daerah Istimewa Jogjakarta. Skripsi. Fakultas Teknobiolgi. Universitas Atmajaya. Yogyakarta.

Niven CF, Jeffrey MB, Corlett DA. 1981. Differential plating medium for quantitative detection of histamine-producing bacteria. Applied and Environmental Microbiology. 41 (1): 321-322.

Puri AA. 2016. Uji bakteriologis dan organoleptik ikan tongkol di pasar tradisional, modern, dan gudang lelang kota Bandar lampung.[Skripsi]. Fakultas Pertanian Universitas Lampung. Bandar Lampung

Sumner J, Ross T, Ababouch L. 2004. Application of Risk Assessment in The Fish Industry. Rome (IT): FAO.

Saanin H. 1984. Taksonomi dan kunci identifikasi ikan. Jilid I dan II. Bina Cipta. Bogor.

Setiawan A, Supriyadi F, Noor GE, Fadli M, Murdimanto A. 2016. Profil Kelautan dan perikanan Kepulauan Sangihe dan Kabupaten Talaud, Proponsi Sulawesi Utara. Badan Litbang Kelautan dan Perikanan. Kementrian Kelautan dan Perikanan

Trilaksani W, Bintang M, Monintja DR, Hubeis M. 2009. Asesmen semi-kuantitatif risiko histamin ikan tuna dari tempat pendaratan (Transit 14). Jurnal Ilmu dan Teknologi Pangan. 7(2):215224.

Wodi SIM, Trilaksani W, Nurimala M. 2014. Perubahan mioglobin tuna mata besar selama penyimpanan suhu chilling. Jurnal Pengolahan Hasil Perikanan Indonesia. Vol 13(2):185-192.

Wodi SIM, Trilaksani W, Nurimala M. 2018. Histamin dan identifikasi bakteri pembentuk histamin pada tuna mata besar (Thunnus obesus). Jurnal Teknologi Perikanan dan Kelautan. Vol 9(2):185-192. 